\title{
Debate Liberal Comunitarista: Sandel Contra Rawls
}

Flávio Azevedo Reis

I am constant as the northern star, Of whose true-fixed and resting quality

There is no fellow in the firmament.

-Julius Ceaser, Shakeapeare.

\section{Resumo:}

Pretende-se apresentar a crítica comunitarista de Michael Sandel ao liberalismo de Rawls. Há dois pontos principais. O primeiro é mostrar como Sandel interpreta o pensamento de Rawls e como esta leitura suporta a sua crítica ao liberalismo. O segundo é apontar para uma falha na interpretação de Sandel, de forma que possamos apresentar os limites de sua crítica.

Palavras-chave: Política, justiça, liberalismo, comunitarismo. 
O livro Liberalism and the limits of justice, de Michael Sandel, representa uma crítica importante ao liberalismo de John Rawls. Grosso modo, o seu objetivo é mostrar que o liberalismo de Rawls fracassa porque, ao abordar a questão da "universalidade" e "neutralidade" da justiça, ele acaba formulando uma concepção de justiça irrealista que pressupõe relações sociais atomizadas e individualistas. $\mathrm{O}$ nosso objetivo aqui é discutir essas questões a partir da leitura feita por Sandel. Serão mostradas, portanto, tanto a forma como Sandel interpretou o pensamento de Rawls quanto os problemas e defeitos desta leitura. A tese central é que a crítica de Sandel não é válida por que ela se baseia em uma leitura equivocada da filosofia de Rawls.

Segundo Sandel, Rawls pretende que a justiça tenha o papel moral de servir como "critério de avaliação" quase-transcendental sobre as diversas concepções de bem (concepções religiosas filosóficas e/ou morais) existentes na sociedade e, assim, determinaria quais são as concepções permissíveis. Neste sentido, o right tem prioridade sobre o bem porque a justiça serve como árbitro para julgar conflitos entre concepções de bem e também definir quais concepções são permissíveis. Segundo Sandel, este é o aspecto "moral” da deontologia liberal: um conjunto de valores categóricos que tem prioridade moral em relação aos outros valores presentes na sociedade. Para que este aspecto moral seja eficaz, é preciso que a deontologia também seja acompanhada de seu sentido fundacional, ou seja, que o right ou a justiça possam ser fundamentados de forma a não depender de alguma concepção de bem em particular ${ }^{\mathrm{I}}$.

Esta leitura pressupõe uma ambigüidade (e uma tensão) interna ao pensamento de Rawls. Por um lado, há a contingência empírica das diversas concepções de bem e dos diversos valores concorrentes que existem nas sociedades contemporâneas. Por outro, há a necessidade moral de apresentar algum valor moral de right ou justiça que possa servir de critério de avaliação daqueles valores contingentes. O problema é saber como "fundamentar" estes valores de maneira independente, para garantir que eles realmente tenham esta prioridade. Este problema se torna ainda mais complexo quando se considera que a "fundamentação" não pode ser a priori ${ }^{2}$. A formulação da teoria da justiça deve

\footnotetext{
I "No sentido moral, deontologia se opõe ao consequencialismo: ela descreve um ética de primeira ordem que contem certas obrigações categóricas e proibições que tem precedência em relação a outras preocupações morais e práticas. No sentido fundacional, deontologia se opõe à teleologia: ela descreve uma forma de justificação na qual os princípios são derivados de maneira a não pressupor quais são os fins ou propósitos humanos, ou qualquer concepção determinada de bem”. (SANDEL, I998, p.3)

2 "A análise dos conceitos morais e dos seus a priori, como quer que sejam entendidos tradicionalmente, é uma base frágil demais. A filosofia deve ter a liberdade de usar hipóteses contingentes e fatos genéricos como lhe aprouver." (RAWLS, 2002, p.55)
} 
levar em conta o contexto de sua aplicação, ela não deve ser uma teoria totalmente distante da realidade. Assim, há duas exigências conflitantes para a teoria: por um lado, é preciso que justiça tenha prioridade em relação aos fatos sociais contingentes (em especial as concepções de bem); por outro lado, ela precisa levar em consideração estes mesmos fatos contingentes para que a sua formulação tenha alguma relação com a realidade na qual ela será aplicada.

O ponto mais importante da leitura de Sandel é o seguinte: a forma pela qual se fundamenta a concepção de justiça está ligada a uma concepção de natureza humana. Para Sandel, a maneira como se concebe a relação entre a justiça e o bem depende da forma como se concebe a relação entre o sujeito e seus fins. Uma concepção de justiça derivada de forma a priori (sem nenhuma relação com os valores empiricamente dados em uma sociedade) depende, segundo Sandel, de uma noção de sujeito capaz de se desvincular totalmente de suas determinações empíricas (sujeito desencarnado). Por outro lado, uma concepção de justiça derivada a partir dos valores morais de uma determinada sociedade pressupõe uma concepção de sujeito como totalmente determinado pela sua situação empírica (sujeito radicalmente situado). Esta é uma tese central para a sua argumentação: a forma pela qual se deriva a concepção de justiça depende da forma como se concebe o sujeito. Uma concepção de justiça desvinculada da situação empírica depende de uma noção de sujeito também desvinculado de sua situação empírica. Uma concepção de justiça derivada de dados empíricos depende de uma noção de sujeito vinculado a sua situação empírica.

Ao comentar Rawls, Sandel diz que ele não deixou explícito qual seria a concepção de natureza humana que se liga à sua teoria da justiça. O esforço de Sandel é, portanto, encontrar qual seria a concepção de natureza humana (mais especificamente, a resposta à questão da relação entre o sujeito e suas determinações empíricas) que estaria presente nas entrelinhas dos textos de Rawls. Assim, entender como Rawls relaciona a justiça e o bem abre portas para pensar como ele concebe o sujeito.

Sandel diz que ambas as alternativas apontadas acima são inaceitáveis para Rawls. Ele indica a necessidade de Rawls encontrar um "ponto arquimediano" entre estas duas alternativas. Para que a justiça possa servir como critério de avaliação, é necessário distinguir o critério de avaliação da coisa avaliada. Portanto, não é aceitável derivar a concepção de justiça a partir dos dados empíricos, pois isto resultaria apenas na justificação de práticas já existentes. Sem uma distinção clara entre o critério de avaliação e a coisa avaliada, a justiça não poderia servir como "ponto de vista crítico" a partir do qual se poderia julgar as diversas concepções de bem. Por outro lado, seria igualmente insatisfatório derivar a concepção de justiça a partir de dados puramente abstratos, sem relação alguma 
com a realidade empírica a qual ela irá se aplicar. Uma derivação a priori seria infundada (groundless) . O projeto teórico rawlsiano, segundo Sandel, seria o de derivar uma concepção de justiça que, ao mesmo tempo, seja independente das circunstâncias empíricas (de forma que esta concepção de justiça sirva de ponto de vista crítico e garanta a primazia da justiça sobre o bem), mas também mantenha alguma relação com estas circunstâncias de forma que a concepção não se torne infundada (groundless) ${ }^{3}$ e arbitrária. O desafio é encontrar um equilíbrio entre estas duas exigências antagônicas: uma concepção de justiça que ao mesmo tempo seja fundamentada independentemente dos valores pré-existentes em uma sociedade, mas que possa ser aplicável a uma sociedade real.

Segundo Sandel, Rawls teria combinado elementos em sua teoria que permitem pesar ambas as exigências. Ele teria encontrado um "ponto arquimediano". Por um lado, na situação contratual, as partes escolhem os princípios de justiça sob um "véu de ignorância” que as impede de saber quais são as suas concepções de bem, a suas localizações na sociedade, suas características psicológicas etc. Isto garante que a decisão não seja diretamente vinculada a interesses empiricamente dados. A concepção de justiça escolhida neste contrato hipotético mantém uma certa independência em relação às condições empíricas. Por outro lado, a construção desta situação contratual (a posição original) leva em consideração a concepção de "circunstâncias da justiça" ${ }^{4}$, ou seja, as condições de aplicação da concepção de justiça. Desta forma, a situação contratual inclui elementos que indicam a sua aplicação a sociedade de homens reais.

O problema do conflito entre fundamentação e aplicação ganha uma nova faceta neste momento. Se Rawls inclui considerações empíricas, sob a forma das "circunstâncias da justiça”, então a sua teoria abarcaria várias contradições. Seriam duas exigências aparentemente incompatíveis: por um lado, uma concepção afastada das considerações empíricas garante a primazia da justiça,

3 "As duas possibilidades se mostram como igualmente insatisfatórias: se os princípios de justiça são derivados dos valores ou concepções de bem correntes em uma sociedade, não há como assegurar que o seu ponto de vista crítico seja mais válido do que as concepções que eles pretendem regular, pois, como um produto desses valores, a justiça estaria submetida às mesmas contingências. Uma alternativa seria um padrão externo aos valores e interesses que prevalescem em uma sociedade. Porém, se a nossa experiência for desqualificada inteiramente enquanto fonte destes princípios, essa alternativa teria que se basear em pressupostos a priori cujas crendenciais seriam igualmente suspeitas, mesmo que por razões opostas. Enquanto o primeiro seria arbitrário por ser contingente, o segundo seria arbitrário por ser infundado [groundless].” (SANDEL, I998, p.I7)

4 "Seguindo Hume, Rawls nota que as circunstâncias da justiça são de dois tipos: objetivas e subjetivas. As circunstâncias objetivas incluem fatos como a escassez moderada de recursos, enquanto as circunstâncias subjetivas tratam dos sujeitos da cooperação, notadamente o fato de que eles são caracterizados por diferentes interesses e fins." (SANDEL, I998, p.29) 